\title{
Pedagogical Innovation: Towards Conservation Psychology and Sustainability
}

\author{
Marco Heredia-R ${ }^{1,2, *}$, Karina Falconí ${ }^{3}$, Jhenny Cayambe ${ }^{4}$, Sylvia Becerra $^{5}$ \\ ${ }^{1}$ Department of Life Sciences, Universidad Estatal Amazónica, Puyo, 160101, Pastaza, Ecuador \\ ${ }^{2}$ Natural Resources Economics and Business Development Program, Universidad Estatal Amazónica, Puyo, 160101, Pastaza, Ecuador \\ ${ }^{3}$ Faculty of Economic and Administrative Sciences, Universidad de las Américas. Quito, 170125, Pichincha, Ecuador \\ ${ }^{4}$ School of Agricultural and Environmental Sciences, Pontificia Universidad Católica del Ecuador Sede Ibarra, 100112, Imbabura, \\ Ecuador \\ ${ }^{5}$ Géoscience Environment Toulouse, Université de Toulouse, CNRS, IRD, UPS, Toulouse, France
}

Received April 18, 2020; Revised December 7, 2020; Accepted January 25, 2021

\section{Cite This Paper in the following Citation Styles}

(a): [1] Marco Heredia-R, Karina Falconí, Jhenny Cayambe, Sylvia Becerra , "Pedagogical Innovation: Towards Conservation Psychology and Sustainability," Universal Journal of Educational Research, Vol. 9, No. 4, pp. 771 - 780, 2021. DOI: 10.13189/ujer.2021.090409.

(b): Marco Heredia-R, Karina Falconí, Jhenny Cayambe, Sylvia Becerra (2021). Pedagogical Innovation: Towards Conservation Psychology and Sustainability. Universal Journal of Educational Research, 9(4), 771 - 780. DOI: 10.13189/ujer.2021.090409.

Copyright $\odot 2021$ by authors, all rights reserved. Authors agree that this article remains permanently open access under the terms of the Creative Commons Attribution License 4.0 International License

\begin{abstract}
Pedagogical innovation is one of the solutions to the challenges facing the educational system; it is a mediator for change and adaptation. The objective of education is to go more than rationality and involve creativity; the development of creativity is increasingly considered in the teaching-learning processes. The objective of the research was to compare the perception of university students about theater as a pedagogical tool with the scientific evidence and its contribution to the conservation of natural resources, at the Universidad Estatal Amazónica (Ecuadorian Amazon Region); four plays were performed during the academic periods: 1) 2018 - 2019, 2) 2019 - 2019 y 3) 2019 - 2020. Four didactic phases were developed in each period; a survey with four closed questions based on the Likert scale was applied to 247 students. It was evident that more than 50\% and $31 \%$ students totally agree that theater is a new pedagogical tool and can be used as a learning mechanism, respectively; the $7 \%$ of students on average consider that theater is probably related to conservation psychology, despite the fact that there is evidence of its potential for forest care and management. The $62 \%$ totally agree that the theater promotes the sustainability of natural resources. Therefore, theater is considered to be effective in raising awareness and educating on natural resource issues and breaking down misconceptions about their conservation.
\end{abstract}

Keywords Amazonia, Pedagogical Tool, Sustainability, Teaching, Theater

\section{Introduction}

Pedagogy describes the philosophical and empirical traditions that address how young people learn and how the teacher / instructor approaches the learning environment. From a pedagogical perspective, students: (1) depend on teachers' instructions, (2) have little experience with course content, (3) need to be directed towards what and when to learn, (4) focus on the subject at hand, and (5) are motivated to learn by external forces [1]. It is considered that the science is in charge of education as a human phenomenon, it is permanent discussion in search of qualifying the pedagogical act of the classrooms to contribute more effectively to the training of present and future generations, and thus build the communities of knowledge and lifelong learning for a globalized society [2].

In the complex sociopolitical-economic academic context of Ecuador, pedagogical innovation is one of the solutions to the challenges facing the educational system. It 
is a mediator for change and adaptation, marked more by human interaction than by technique, supporting students and facilitating learning and teaching [3]. There are different definitions for the concept of pedagogical innovation. Initially, pedagogical innovation is described as: (1) an intentional improvement, measurable and sustainable that is unlikely to occur frequently [4], (2) represents a logical notion defined as "an intentional action that aims to introduce something original into a context, and that seeks to improve student learning in a situation of interaction and interactivity [5], (3) often described as anything but a master class, method still used by most teachers [6].

Pedagogical innovation involves guaranteeing and implementing the acceptance and widespread use of a change that survives without altering its initial characteristics. This is classified into 11 types in higher education: (1) computer use, (2) personal communication and problem solving skills, (3) team projects and collaborative-cooperative learning, (4) oral presentations of the students (individual and group), (5) interactive lectures and tutorials, (6) work-based learning, (7) problem-based learning, (8) resource-based learning, (9) open and distance learning, (10) peer tutoring or assessment, and (11) others (student-led learning, log books, portfolios, reflective practices) [7].

The forms of thought promoted in the arts can be useful, when the objective of education is to go beyond rationality and involve creativity [8], the development of creativity is increasingly seen as an educational imperative. Two forces drive a greater emphasis on creativity, individual student achievement, and future success as participants in the knowledge-based economy [9]. However, current educational strategies are limited to teaching rigid models that do not encourage creativity and encourage the acquisition of knowledge about creative exploration; teaching / learning processes are based on repetition and memorization. Theater is a highly interactive activity that rewards the development of skills such as active listening, acceptance, non-verbal communication, interpersonal trust and support among students [10], and it allows a permanent and functional learning process [11].

There are two arguments to justify theater as an innovation in teaching-learning processes: (1) the contextualist approach, uses art as a means to achieve a particular objective, such as: helping to learn history or stimulating creativity, through complex creative thinking [8] and (2) the essentialist approach, conceives art as a very particular and valuable experience in the Deweyan sense [12], that it has a particular continuity for each individual, activates the sensitivity of the observer and promotes the expression of its values. The objective of the research was to compare the perception of university students about theater as a pedagogical tool with scientific evidence and its contribution to the conservation of natural resources.

\section{Methodology}

\subsection{Phase of the Didactic Process}

As a pedagogical innovation methodology and training activity in the Sustainable Development course of the Environmental Engineering Degree at the Universidad Estatal Amazónica, located in the Ecuadorian Amazon Region (EAR), four theater plays were held during academic periods: 1) 2018 - 2019, 2) 2019-2019 y 3) 2019 - 2020, in each academic period, four didactic phases were developed:

Phase 1. Induction on the importance of theater and its relationship with the conservation of natural resources

The students developed cognitive skills were developed with social intervention methodologies, they acquired theoretical knowledge that favors the understanding of this technique and its development. For each academic period, a two-hour training talk was held, the topics covered were: integration of the arts in educational systems [13], the relationship of creativity with theater [14], theater as a tool in public health systems [15], as an innovative method to support the management and conservation of natural resources [16], and for rural transformation [17].

Phase 2. Configuration of theater groups and production of the theater play

Theater groups were set up based on the number of students per academic period: 1) 2018 - 2019, 2) 2019 2019 y 3) 2019 - 2020, number of students: 115 , 67 y 65 , respectively. For the production of theater plays two tasks were developed: 1) creation of the theater play and 2) essays. For the creation of the theater play the guidelines were: a) Distribution of functions: researchers, actresses / actors, director, screenwriters, props and scenery, reportage and photography, each student could take on more than one role; b) Research process: the students with the functions of researchers investigate the rural dynamics of the places where the theater plays will be presented; c) Selection of themes to present and creation of the theater play: With the identified rural dynamics, a merger with the Sustainable Development Goals (SDGs) was carried out for each theater play, with a duration of between 60 and 70 minutes.; d) Essays: it is a process of construction and reflection of the theater play created and identification of problems and timely solutions.

\section{Phase 3. Presentation of the theater plays}

The four theatrical presentations were made in the city of Puyo (Ecuador), an inference was made for their potential application in the main areas of natural and cultural importance located in the central and northern areas of the EAR: Cuyabeno Wildlife Production Reserve (CWPR), Yasuní Biosphere Reserve (YBR), Sumaco Biosphere Reserve (SBR) y LLanganates Sangay Ecological Corridor (LLSEC) (Fig. 1). 
In the three theater plays 247 students participated, with an average age of 23 years. In the Table 1 shows the academic periods, protected areas, titles of theater plays and distribution of students according to protected areas.
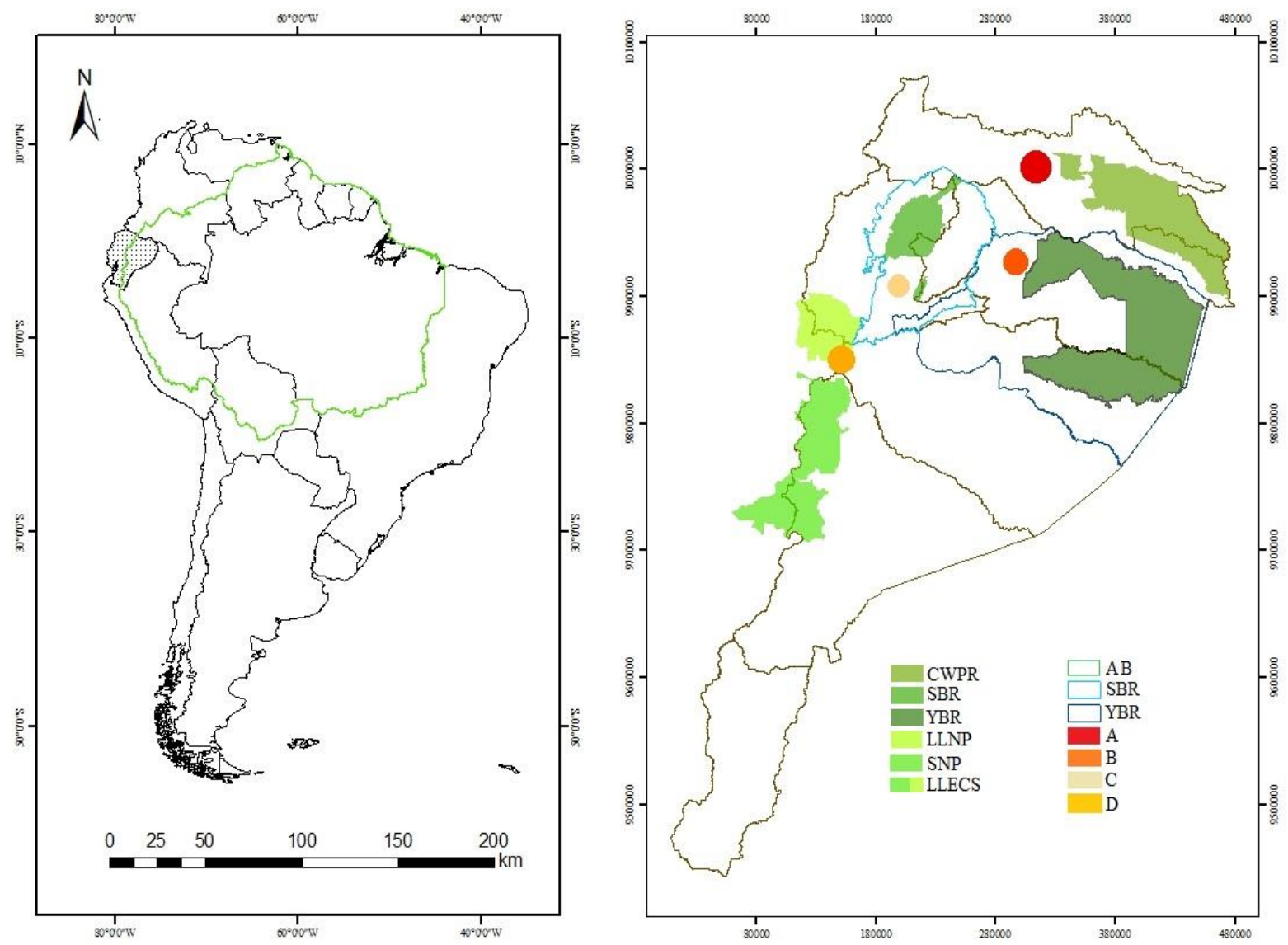

Figure 1. Places of presentation of the theater plays in the Ecuadorian Amazon Region

Table 1.Distribution of theater plays according to academic periods and area of protection of natural resources.

\begin{tabular}{ccccc}
\hline Academic period & $\begin{array}{c}\text { Protected area / Denomination for the } \\
\text { protection of natural resources }\end{array}$ & $\begin{array}{c}\text { Title of the } \\
\text { theater play }\end{array}$ & Number of students & $\begin{array}{c}\text { Code by } \\
\text { theater play }\end{array}$ \\
\hline $2019-2020$ & Yasuní Biosphere Reserve (YBR) & $\begin{array}{c}\text { Sustainable cities } \\
\text { andcommunities }\end{array}$ & 65 & $\mathrm{~A}$ \\
$2019-2019$ & Cuyabeno Wildlife Production Reserve (CWPR) & A trip to my planet & 67 & $\mathrm{~B}$ \\
$2018-2019$ & $\begin{array}{c}\text { Sumaco Biosphere Reserve (SBR) } \\
\text { LLanganates Sangay Ecological } \\
\text { Corridor (LLEC) }\end{array}$ & $\begin{array}{c}\text { An emergency } \\
\text { patient }\end{array}$ & 52 & $\mathrm{C}$ \\
\hline
\end{tabular}




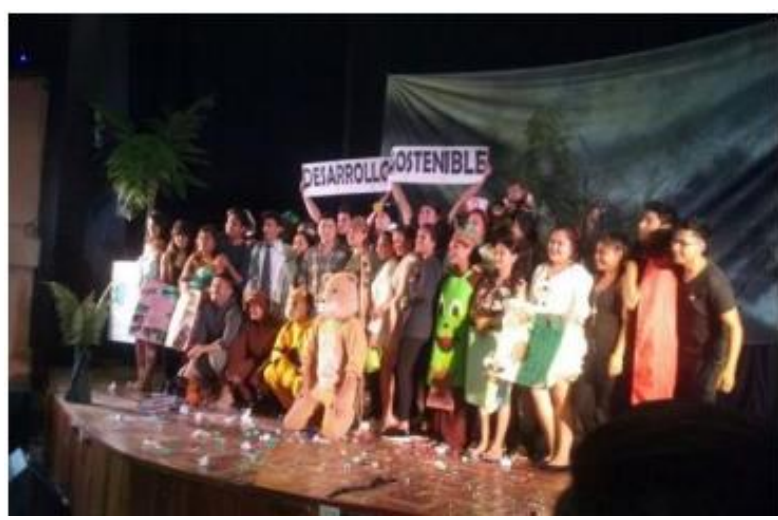

Figure 2. Sustainable cities and communities for the YBR

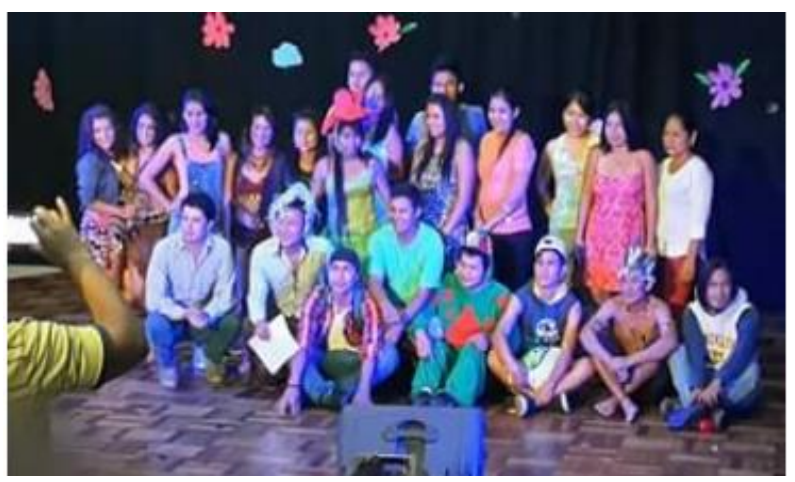

Figure 3. A trip to my planet for the CWPR

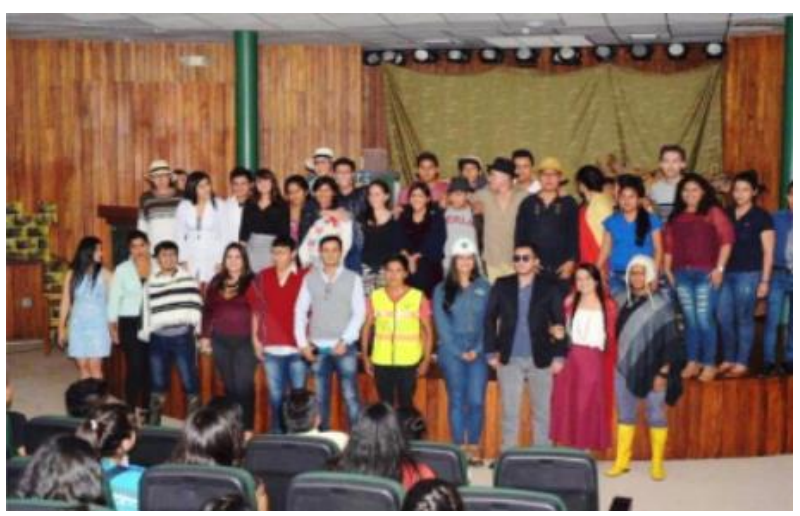

Figure 4. An emergency patient for the LLSEC

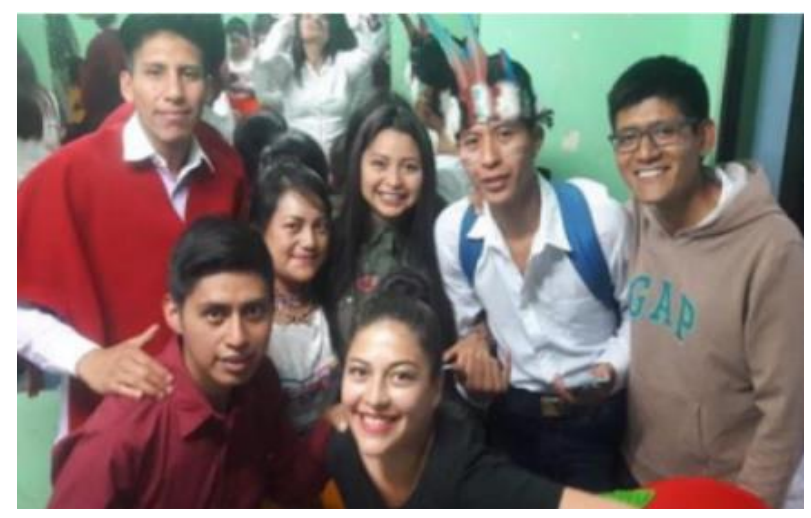

Figure 5. An emergency patient for the SBR
Phase 4. Evaluation of the experience

After the theater plays, two dimensions were evaluated: theater 1) as an innovative pedagogical tool and learning mechanism and 2) its relationship with the psychology of conservation and sustainability of natural resources. A survey with four closed questions based on the Likert scale with five response options was applied: 1) totally agree, 2) mostly agree, 3) probably, 4) mostly disagree, 5) totally disagree; to the 247 participating students

\section{Results and Discussion}

\subsection{Theater as a Pedagogical Tool is a New Idea}

In the four theatrical performances, more than $50 \%$ of the students totally agree and the average $31 \%$ mostly agree (Fig. 6), that the theater is a new pedagogical tool, but the literature indicates that it has been used as a teaching resource in different times and situations, began with the theatrical dialogues created by the humanist Juan Luis Vives for teaching Latin to university students during the Renaissance (XV - XVI century) [18], it had a didactic function in the Jesuit and Salesian schools (XVI century) where it was integrated into teaching activities in all disciplines and school training [19].

The theater has generated various potentials, such as: integration into a process of curricular connections and collaborative commitments. [20], It has been demonstrated in different pedagogical settings: theater has a long tradition in education, in 1980, Charles William Eliot, president of Harvard, argued that theater develops a sense of right, duty, and honor, along with the necessary communication skills in the business areas [21].

The result of a meta-analysis developed over a period of 20 years (1993 - 2013), on the arts used as a teaching and research instrument, the theater was the most common performing art used [22]. At the University of Carolina at Berkeley College of Arts and Sciences in 2016, 2017, and 2018 with students (151) from different majors: computer science, engineering, economics, architecture, sociology, environmental studies, chemical and biological sciences, the "collaborative innovation" class was created for the integration of art, business and theater, the result was that collaborative teamwork, helps tackle social problems, and opens up unexpectedly challenging potential for the development of students as future contributors to society [23].

The $8 \%$ of the students participating in the four theater plays consider that the theater is probably a new tool in pedagogy, while literature mentions that in Finland the integration of theater and other performing arts such as dance, music, cinema, occurs at scale throughout the national educational system with the active participation of students and teachers more than a decade ago [24], and 3\% and $4 \%$ of the students who performed the plays for 
theCWPR and LLSEC, respectively, this mostly disagree and only $2 \%$ and $3 \%$ totally disagree; showing that only nine students have some kind of knowledge about the performing arts and its history in the teaching learning processes; evidencing a scarce formal, informal and non-formal education in this area of knowledge.

\subsection{Theater Can be Used as a Learning Mechanism}

In question \# 2, of the participating students, $49 \%$ who presented the theater plays for the SBR and YBR, and 8\% for LLECS (much less than in other places), are totally agree (Fig. 7); which corroborates that the theater offers new opportunities for students to apply skills they have learned from other disciplines such as: history, science and human nature, etc. [25], develops various skills such as empathy as: clinical empathy, a critical skill for the doctor-patient relationship [26], favors the growth of society and incorporates tools such as: 1) understand human experiences of the past and present, 2) learn to adapt and respect different ways of thinking, working and expressing; it generates an institutional transformation, towards a work environment, with better interpersonal relationships and to increase the capacity of strategic alliances between institutions, which implies a change in management policies, such as: improving benefits for the most vulnerable groups [27] and in the audience it generates a change of thought on a particular topic and gives them new ideas.

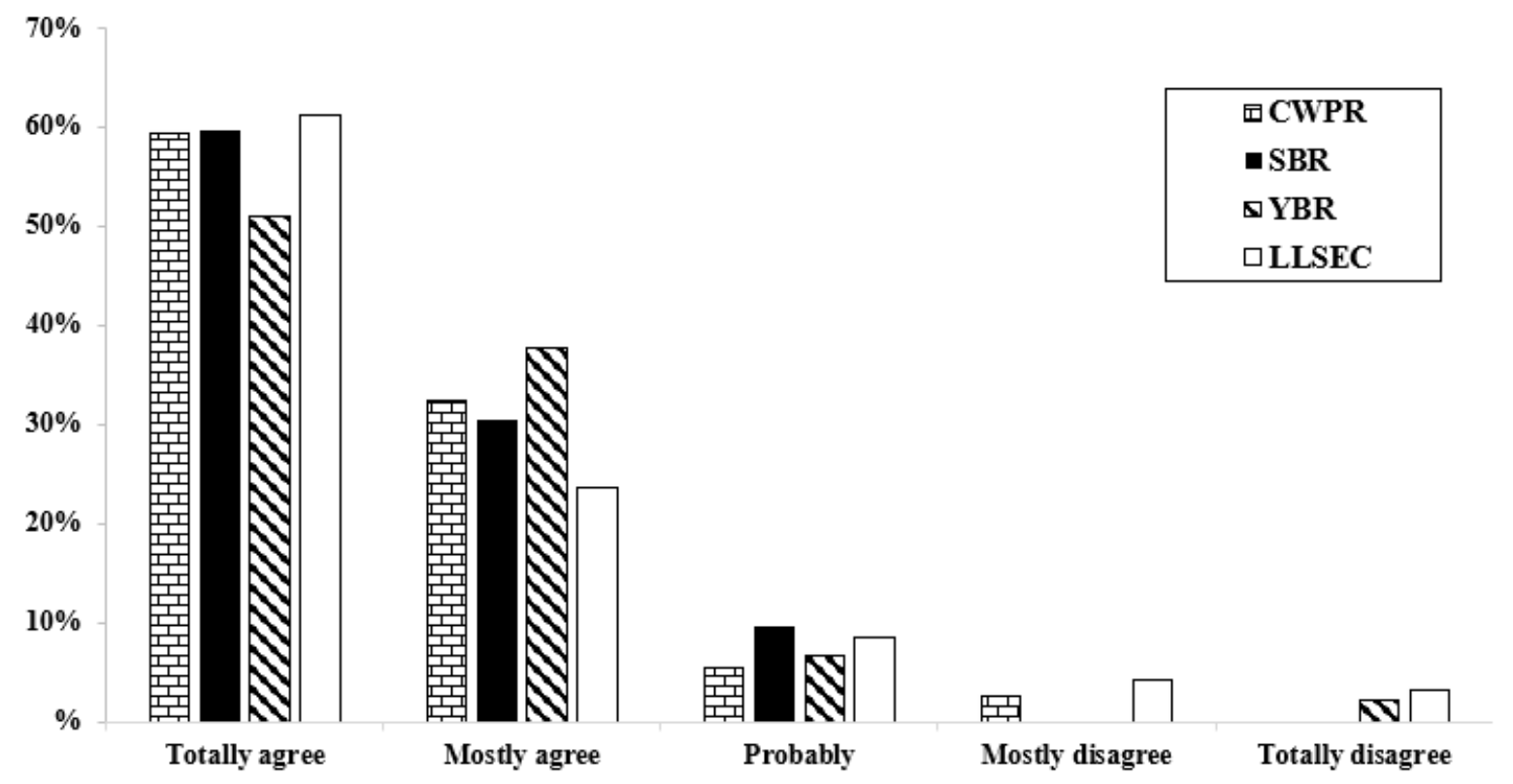

Figure 6. Histogram with the results based on question \# 1 of the survey: the theater as a pedagogical tool is a new idea.

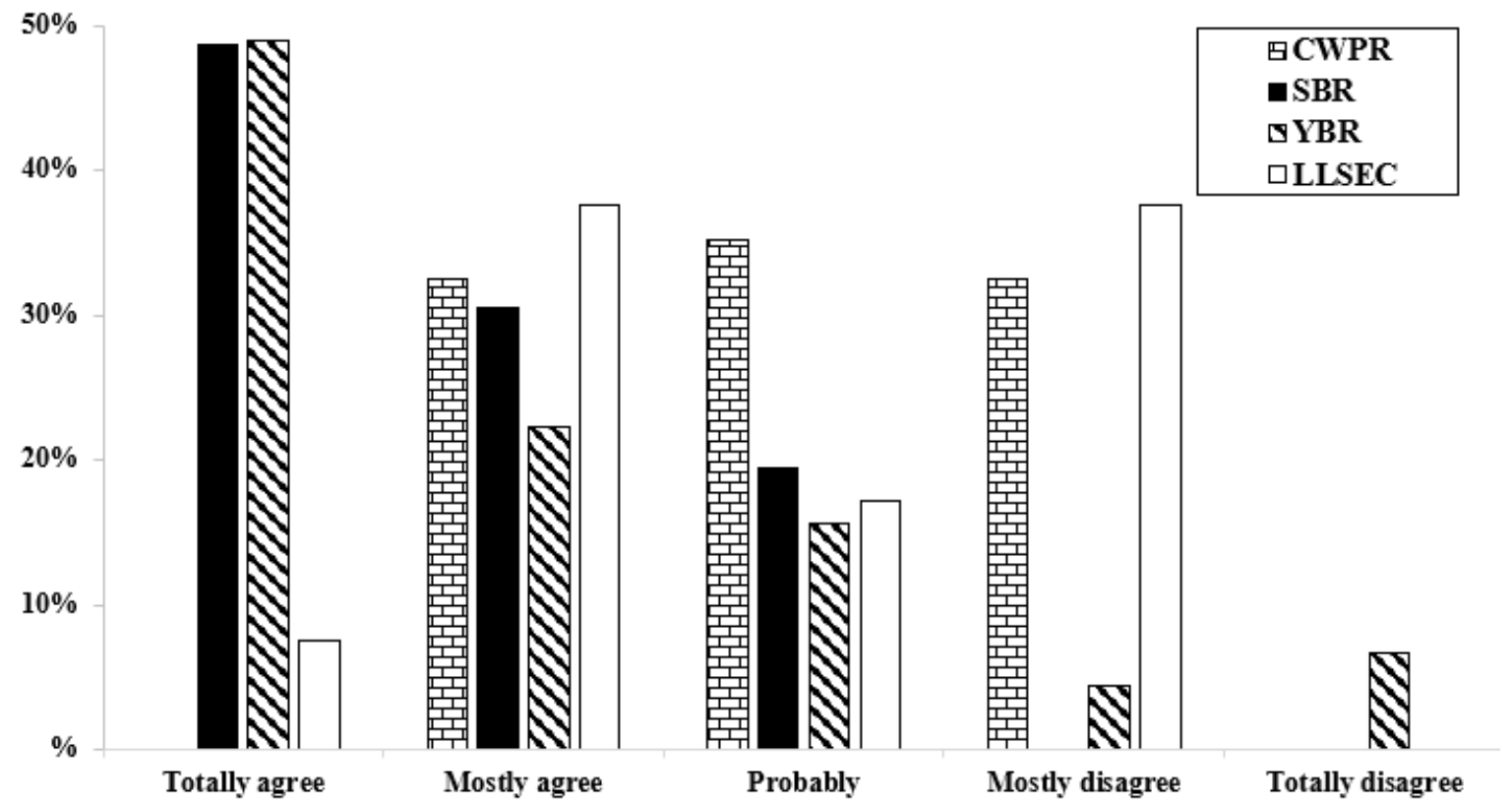

Figure 7. Histogram with the results based on question \# 2 of the survey: theater can be used as a learning mechanism 
The students who presented the plays for: CWPR, SBR, YBR and LLSEC, totally agree with $32 \%, 31 \%, 22 \%$ and $38 \%$, respectively, that theater alphabetization prepares students to work collaboratively, participate in social networks, negotiate cultural differences, criticize existing paradigms, navigate contradictory data [28], enhances spatial thinking, abstract reasoning, and active listening and observation skills [29].

Based on the learning theory, constructivism is the theory of teaching and learning, it states that knowledge cannot be transmitted from a teacher to a student but must be built by each student through the interpretation and reinterpretation of a constant flow of information [30], analogous process the problem-based learning (PBL) educational method [31].

Starting in the 1990s, there is an interest in art-based research (ABR), first used in 1993 by the erudite Elliot Eisner [32] and implemented in various pedagogical settings such as the University of Arkansas in the history course, where the positive effects of theater as a pedagogical tool were demonstrated [33] and the research line has been formulated in: Proposals for the development and implementation of theatrical education at different educational levels and stages, from early childhood education to professional training, precisely establishing the subjects that can be articulated as a line of investigation [34].

The education is considered as the way for the integral formation of the human being, its objective should not be limited only to the well-being and responsibility of life, but also to the development of qualities and talents characteristic of each individual; of the students, $22 \%$ considered that the theater can probably be used as a learning mechanism. It is emphasized that education allows us to understand world views, ways of seeing and explaining reality from where new and fun ways of developing act [35], and what better way to preserve the human being in front of the world, if not through the theater, an educational resource through which children with special educational needs can create games, comply with rules, build their spaces and their stories [36].

Although the usefulness of theater in pedagogy is evident $[37,38]$, the $32 \%, 4 \%$ and $38 \%$ who performed the plays for the CWPR, YBR, LLSEC, respectively; they consider that this is most likely not the case, and $7 \%$ of students (SBR) totally disagree with the use of the theater. The lowest values are considered to be related to the participants' precarious level of knowledge about the importance of theater in teaching-learning processes.

\subsection{The Relationship between the Theater with Conservation Psychology}

Question \#3, is related to conservation psychology (CP) which is a part of psychology, studies the behavioral causes and solutions of environmental problems, aims to understand and promote human and nature care [39]. The $\mathrm{CP}$ investigates the interactions between human behavior and the socio-physical environment [40], recognizes and accepts the concept of sustainability [41], which is described in the Brundtland Report and highlights the importance of studying sustainability issues from a psychological perspective, therefore the $\mathrm{CP}$ is directed to study the psychological components involved in sustainable actions called as psychological dimensions of sustainability [42] that involve psychological tendencies and capacities (attitudes, motives, beliefs, norms, pro-environmental abilities, etc.) that influence sustainable behavior (proecological, altruistic, frugal and equitable actions) [43]. In terms of experimental psychology, it was discovered that the incorporation of gestures when learning a new concept increases the retention of knowledge of the students [45]. A theatrical experience in the community of Cherán (Mexico) explored the positive potential of theater in conservation psychology, for community forest care and management. [16].

In the same way, on average $62 \%$ and $25 \%$ of the students in the four scenarios totally agree and mostly agree, respectively, that the theater is related to conservation psychology as: instrument of behavior change and way of thinking (Fig. 8): Theater helps to break the invisible, often abstract concept with something real and present, especially when it is performed with the language that people know [44].

The $7 \%$ of students on average consider that theater is probably related to conservation psychology; when the theater provides a space and time for connection and human consciousness instead of cultural exclusion and marginalization [46], it is also considered as a tool for development (Theater for Development - TFD), it is alid of the environmental sociology, since it deals with a connection at the community level, not only at the level of individual behavior or attitudes; in Brazil, in the state of Paraiba, it was used as a tool that promotes or advocates for problems in communities to raise awareness about the proper use of resources and promote food security and sovereignty [47]. In this year in Ecuador, the theater play Nahuel and the bear of Anteojos premiered; that seeks to make people aware of the excessive consumption of plastic, the over-exploration of natural resources and the invasion of humanity, criticizes polluting industries [48]. 


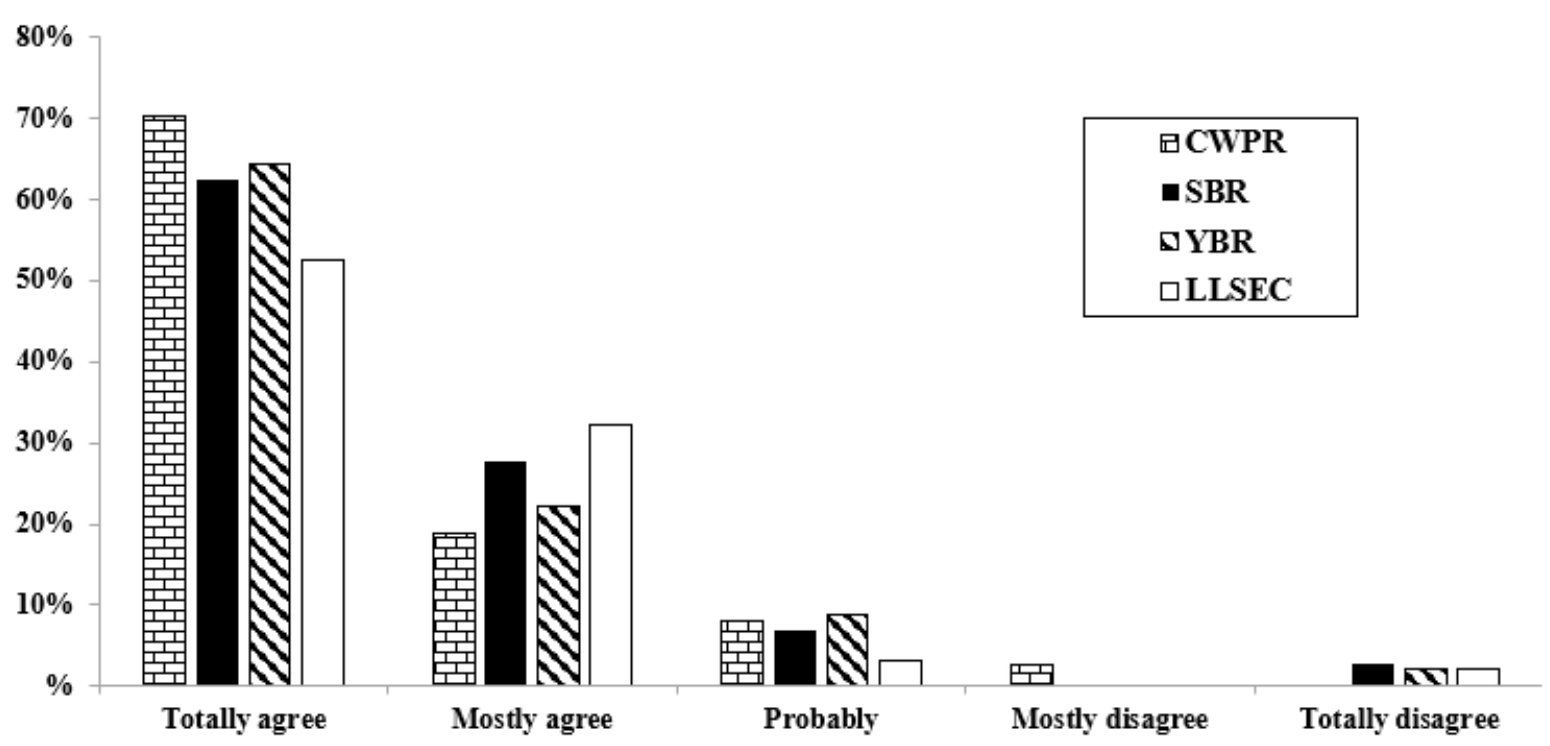

Figure 8. Histogram Question \# 3 of the survey, which deals with the relationship between theater with conservation psychology.

\subsection{The Theater is a Tool to Promote the Sustainability of Natural Resources}

The concept of sustainability arises in forestry, where its meaning is never to harvest more than what the forest produces in new growth [49] the word Nachhaltigkeit (German term for sustainability) was first used with this meaning in 1713 [50]. The $62 \%$ of the participating students are totally agree, that the theater encourages the sustainability of natural resources (Fig. 9); theater is effective in raising awareness and educating rural people about natural resource issues and breaking down misconceptions about their conservation as: forest burning, removal of nitrogen-fixing trees; the theater is a sustainable alternative tool to communicate the importance of the sustainability of natural resources in rural areas, in 2016, this was demonstrated in Gaga, which is a rural settlement located in the local municipality Raymond Mhlaba of the Eastern Cape Province, South Africa [51].

To date, efforts to educate the public and raise awareness about the conservation of natural resources depend on conventional social campaigns [52]. The use of the mass media may be ideal to reach varied and extended audiences, but it has been shown that its consumption generates a discard or the information is ignored [53]. The $25 \%$ of the participants mostly agree with question \# 4 , agreeing that theater is effective in communicating sensitive issues, stimulates community action, gives voice to the voiceless and can be a sustainable tool for sensitivity and mobilization in rural sectors [54]. It allows rural sectors to participate in all its stages of the production of the work, from the collection of information, the development of the story, to the rehearsal and the actual performance [55].

In question 4 , on average, $7 \%$ of students consider that probability theater is a tool to promote the sustainability of natural resources, showing that there are doubts among students about the potential of theater, when it is a platform powerful to mobilize people to the environmental conservation; Turning conservation issues into theatrical performances is a real way of making issues resonate among rural dwellers [56], making a play at the rural level is cheap, flexible, and more current than other media, it doesn't depend of theliteracy, and it is a true two-way media because the public can also participate in the theater [57]. The active participation of communities is essential to generate and promote the management of natural resources and their sustainability [16].

In many developing countries, theater has proven to be an effective strategy to raise awareness, mobilize and influence change of attitude towards environmental problems. In Papua New Guinea, theater was used to bring about a change in the community's attitude towards logging [58]. Similar conservation behavior was achieved in the Korup and Banyang-Mbo area of Cameroon, where the use of the theater not only helped discourage the use of dynamites and chemicals to kill fish and hunt down foreign forest hunters, but also offered marginal men and women the platform to be heard without charges [54].

An awareness and education program increases knowledge on the subject and facilitates change of attitude [59], the knowledge has been shown to be generally assumed to be an essential prerequisite for an individual's behavior [60], that behaving responsibly towards the environment is closely related to an individual's level of consciousness about environmental problems [61]. Theater manages to mentally engage communities [54] and connect them emotionally with their socio-ecological systems [16]. Theater was shown to help deepen understanding of the various concepts surrounding the conservation of natural resources [62]. 


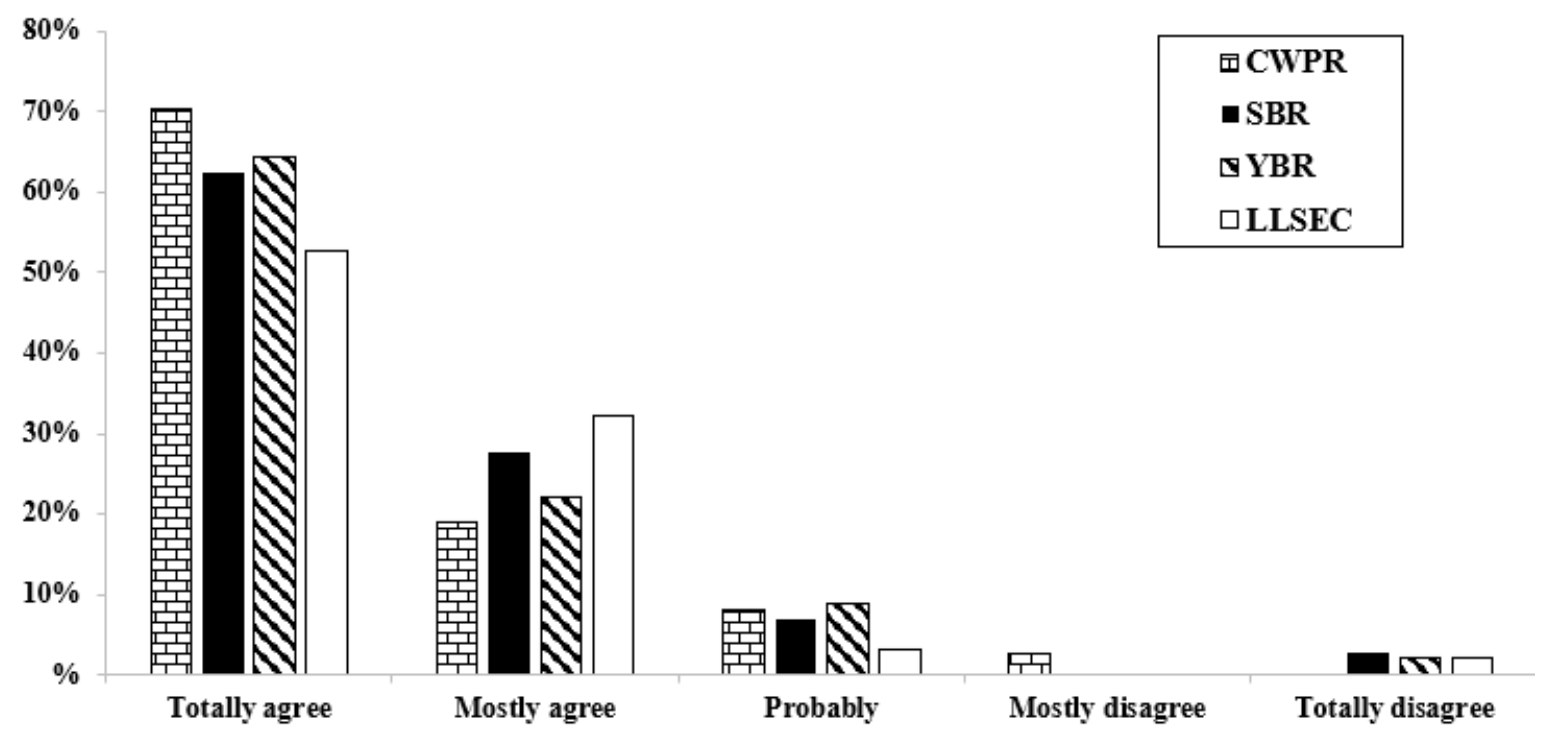

Figure 9. Histogram with the results based on question \# 4 of the survey, that if the theater is a tool to promote the sustainability of natural resources.

\section{Conclusion and Implications}

Theater as a pedagogical innovation in the university educational system of the Ecuadorian Amazon Region, allows the efficient training of professionals, is a tool to enhance the performance of students, their previous experience, the resulting experience and their position within the university.

Theater has the potential to fill knowledge gaps, remove entrenched beliefs, understanding of different disciplines, and leads to a change of opinion or attitude about the conservation of natural resources.The implementation of theater play as a didactic tool, can be considered a privileged way to spread proposals for the conservation of natural resources, in sectors where the media are not well developed; in this context the theater uses a language that people can understand, act in distant places and communicate with audiences with a low level of education.

\section{REFERENCES}

[1] Klatt, B. The ultimate training workshop handbook: A comprehensive guide to leading successful workshops and training programs. McGraw Hill Professional. (1999).

[2] Carbonell, J. Pedagogías del siglo XXI. Alternativas para la innovación educativa ( $3^{\mathrm{a}}$ Edición). Barcelona: Octaedro Editorial. (2015).

[3] Walder, A. M. Le rôle de l'innovation pédagogique au sein de l'université d'aujourd'hui. Chemins de formation au fil du temps, L'université, au carrefour de nouveaux défispédagogiques, Paris: Éditions L'Harmattan, 20, 141-154. (2016).

[4] Huberman, AM. Comment s'opèrent les changementsenéducation: Contribution à l'étude de l'innovation, Série: Expériences et innovations enéducation [How to operate the changes in education: Contribution to the study of innovation, Series: Experiments and innovations in education], Vol. 2, Organisation des Nations Unies pour l'éducation, la science et la culture, Paris, France (1973).

[5] Béchard, J. P. Apprendre à enseigner au supérieur: L'exemple des innovateurspédagogiques. Cahier de recherché OIPG 2000, 1, 1-14. (2000).

[6] Béchard, J. P., \& Pelletier, P. Développement des innovations pédagogiquesen milieu universitaire: un casd'apprentissageorganisationnel. Nouveaux espaces de développementprofessionnel et organisationnel, 131-149. (2001).

[7] Walder, A. M. (Pedagogical innovation: Between social reality and technology. British Journal of Arts and Social Sciences, 18(11), 59-79. 2014).

[8] Eisner, E.W. The arts and the creation of mind. Yale University Press, Yale (2002).

[9] Mullet, D. R., Willerson, A., Lamb, K. N., \& Kettler, T. Examining teacher perceptions of creativity: A systematic review of the literature. Thinking Skills and Creativity, 21, 9-30. (2016).

[10] Dewey, J. Art as experience. Penguin. (2005).

[11] Berk, R. A., \&Trieber, R. H. Whose classroom is it, anyway? Improvisation as a teaching tool. Journal on Excellence in College Teaching, 20(3), 29-60. (2009).

[12] Nihal Kuyumcu, F. Using Theatre Techniques in Foreign Language Education: A Study on Molière's Plays, Procedia Social and Behavioral Sciences, Volume 70, 2013, Pages 6-10, ISSN 1877-0428. (2013).

[13] Robinson, H. A.: Arts integration and the success of disadvantaged students: A research evaluation. Arts Education Policy Review, 114(4), 191-204. https://doi.org/ 10.1080/10632913.2013.826050 (2013).

[14] West, S., Hoff, E., \& Carlsson, I.: Enhancing team creativity 
with playful improvisation theater: a controlled intervention field study. International Journal of Play, 6(3), 283-293 (2017).

[15] Mirabella, G.: Is art therapy a reliable tool for rehabilitating people suffering from brain/mental diseases?. The Journal of Alternative and Complementary Medicine, 21(4), 196-199 (2015).

[16] Heras, M., \&Tàbara, J. D.: Conservation theatre: mirroring experiences and performing stories in community management of natural resources. Society \& Natural Resources, 29(8), 948-964. (2016).

[17] Onyenankeya, K., \&Salawu, A.: Folk Theatre: a potent vehicle for rural transformation. Journal of Multicultural Discourses, 13(4), 348-361 (2018).

[18] Breva-Claramonte, M.: La didáctica de las lenguas en el Renacimiento: Juan Luis Vives y Pedro Simón Abril: con selección de textos (Vol. 25). Universidad de Deusto. (2009).

[19] Desianan C.: Drammatizzazione e Scuola, Firenze. C.D.N., p. 10 (1968).

[20] Burnaford, G., Brown, S., Doherty, J., McLaughlin, H. J. Arts integration frameworks, research \& practice: A literature review. Arts Education Partnership. https://www.aep-arts.org/wp-content/uploads/Arts-Integrati onFrameworks-Research-Practice_A-Literature-Review.pdf. (2007).

[21] Chew, E. B., \& McInnis-Bowers, C. Blending Liberal Art and Business Education. Liberal Education, 90(1), 56- 63. (2004).

[22] S Coemans, S., \& Hannes, K. Researchers under the spell of the arts: Two decades of using arts-based methods in community-based inquiry with vulnerable populations. Educational Research Review, 22, 34-49. (2017).

[23] Beckman, S., Scott, S. J., \& Wymore, L. Collaborative Innovation: Exploring the Intersections among Theater, Art and Business in the Classroom. Journal of Open Innovation: Technology, Market, and Complexity, 4(4), 52. (2018).

[24] Robinson, A. H. Arts integration and the success of disadvantaged students: A research evaluation. Arts Education Policy Review, 114(4), 191-204. (2013).

[25] Martin, A. M. Why theater should be integrated into the curriculum. NASSP Bulletin, 82(597), 30-33. (1998).

[26] Clover, D. Successes and challenges of feminist arts-based participatory methodologies with homeless/streetinvolved women in Victoria. Action Research, 9(1), 12-26. (2011).

[27] Sutton-Brown, C. Women's empowerment in the context of microfinance: A photovoice study. (2011).

[28] Anderson-Inman, L. Thinking between the lines: Literacy and learning in a connected world. On The HorizonThe Strategic Planning Resource for Education Professionals, 17(2), 122-141. (2009).

[29] Seifter, H., Buswick, T., \&Nissley, N. Arts-based learning at work: economic downturns, innovation upturns, and the eminent practicality of arts in business. Journal of Business Strategy. (2010).

[30] Bryson, E. O., \& Levine, A. I. The simulation theater: a theoretical discussion of concepts and constructs that enhance learning. Journal of critical care, 23(2), 185-187. (2008).

[31] De Bruyckere, P., Kirschner, P. A., \& Hulshof, C. D. Myths about Learning. Urban Myths About Learning and Education, 17-92. doi:10.1016/b978-0-12-801537-7.000032 (2015)

[32] A Savin-Baden, M., \& Howell-Major, C. Qualititative Research: The Essential Guide To Theory And Practice. Qualitative Research: The Essential Guide to Theory and Practice. Routledge. (2013).

[33] A Kisida, B., Goodwin, L., \& Bowen, D. H. Teaching History Through Theater: The Effects of Arts Integration on Students' Knowledge and Attitudes. AERA Open, 6(1), 2332858420902712. (2020).

[34] Vieites García, M. F. La construcción de la pedagogía teatral como disciplina científica. Revista española de pedagogía, 493-508. (2013).

[35] Campo, R, Restrepo, M. Formación Integral, Formas En Educación. Facultad de Educación, Pontificia Universidad Javeriana. Bogotá, 12. (1999).

[36] Orozco Peña, Z. El teatro como estrategia didáctica para mejorar la autorregulación de la conducta en niños con TDAH. Escenarios. Vol. 10. 1. 69-8. (2012).

[37] Camargo Plazas, P., Cameron, B. L., Milford, K., Hunt, L. R., Bourque-Bearskin, L., \& Santos Salas, A. Engaging

[38] Indigenous youth through popular theatre: Knowledge mobilization of Indigenous peoples' perspectives on access to healthcare services. Action Research, 17(4), 492-509. (2019).

[39] Lena S. Opfermann. Language, trust and transformation: exploring theatre as a research method with migrant youth, International Journal of Social Research Methodology, 23:2, 139-153, DOI: 10.1080/13645579.2019.1645386. (2020).

[40] Clayton S, Myers G (2009) Conservation psychology. Understanding and promoting human care for nature. Wiley, Oxford.

[41] Clayton, S., Saunders, C. Introducción: Psicología ambiental y de conservación. En The Oxford Handbook ofEnvironmental and Conservation Psychology; Clayton, S., Ed.; Oxford University Press: Oxford, ReinoUnido; pp. 1-6. (2012).

[42] Gifford, R. Environmental psychology and sustainable development: expansion, maturation and challenges. J. Soc. 63, 199-212. (2007)

[43] Corral-Verdugo, V.; Frías-Armenta, M.; García-Cadena, C. Introduction to the psychological dimensions of sustainability. In Psychological Approaches to Sustainability; Corral-Verdugo, V., Frías-Armenta, M., García Cadena, C., Eds.; Nova Science Publishers: New York, NY, USA, pp. 3-18. (2010).

[44] Corral-Verdugo, V.; Montiel-Carvajal, M. Sotomayor-Petterson, M.M.; Frias-Armenta, M.; TapiaFonllem, C Fraijo-Sing, B. Psychological wellbeing as correlate of sustainable behaviors. In Psychology Research Progress.Recent Hispanic Research on Sustainable Behavior and Interbehavioral Psychology; Garcia, C., Corral Verdugo, 
V., Moreno, D., Eds.; Nova Science Publishers: Hauppauge, NY, USA, pp. 27-40. (2013).

[45] Corner, A. The 'art' of climate change communication. Guardian. http://www.guardian.co.uksustainablebusiness /art-climate-change-communication/. (2013).

[46] Cook, S. W., Mitchell, Z., Goldin-Meadow, S. Gesturing makes learning last. Cognition, 106, 1047-1058. https://doi.org/10.1016/j.cognition.2007.04.010. (2007).

[47] Scher, E. Teatro de vecinos. De la comunidad para la comunidad. Buenos Aires: Editorial del Instituto del Teatro.(2010).

[48] Borba, J., Bonatti, M., Sieber, S., \& Müller, K. Theatre methods for food security and sovereignty: A Brazilian scenario. Journal of Rural Studies, 62, 29-39. (2018).

[49] Ordoñez A, Nahuel y la osa de Anteojos [Vídeo]. Disponible en: https://youtu.be/RZaGAapKhTA. (2019).

[50] Wiersum, K.F. 200 Years of Sustainability in Forestry: Lessons from History. Environ. Manage.19, 321-329. (1995).

[51] Wilderer, P.A. Sustainable water resource management: The science behind the scene. Sustain. Sci. 2, 1-4 (2007).

[52] Kevin Onyenankeya \& Abiodun Salawu. Folk Theatre: a potent vehicle for rural transformation, Journal of Multicultural Discourses, 13:4, 348-361, DOI: 10.1080/17447143.2019.1566344. (2018).

[53] Anderson, A. Reflections on environmental communication and the challenges of a new research agenda. Environmental Communication 9, no. 3: 379-383. (2015).

[54] Moser, S.C., and L. Dilling. Communicating climate change: Closing the science-action gap. In Oxford handbook of climate change and society, ed. N. Richard and D. Scholsberg, 161-74. Oxford: Oxford University Press. (2012).
[55] Inyang, E. Community theatre as instrument for community sensitisation and mobilisation. TydskrifvirLetterkunde 53, no. 1: 149-59. (2016).

[56] Chari, T. Rethinking climate change communication strategies in Africa: The case for indigenous media. Indilinga: African Journal of Indigenous Knowledge Systems 15, no. 2: 217-32. (2016).

[57] Nda, U.S., and F. Ekong. Communicating climate change in Africa through the theatre for development Process. Ethiopian Journal of Environmental Studies and Management 5, no. 4: 437-443. (2012)

[58] Kumar, R. Society. Media, communication and development linkages: An analysis of AngloSaxon Theories in the context of developing countries. Journal of Media and Communication Studies 5, no. 3: 25-34 (2013).

[59] Borrini-Feyerabend, G., and D. Buchan. Beyond fences: Seeking social sustainability in conservation. Vol. I: A process companion. Glan: N.P: World Conservation Union. (1997).

[60] Tsatsi, C., U. Mila, S. Mabasa, and S. Pongoma. Conserving a scarce resource. The role that municipality (and all of us) should play to address water conservation and water demand management challenges. IMIESA 35, no. 3: 24-33. (2010).

[61] Mathipa, K.S., and C.S. Le Roux. Determining water management training needs through stakeholder consultation:Building users' capacity to manage their water needs. Water SA 35, no. 3: 253-60. (2009).

[62] Bamberg, S., and G. Möser. Twenty years after Hines, Hungerford, and Tomer: A new metaanalysis of psychosocial determinants of pro-environmental behaviour. Journal of Environmental Psychology 27, no. 1: 14-25. (2007).

[63] Onyenankeya, K., \& Salawu, A. Folk Theatre: a potent vehicle for rural transformation. Journal of MulticulturalDiscourses, 13(4), 348-361. doi:10.1080/1744 7143.2019.1566344. (2018) 